\title{
Assessment of vaccine efficacy by challenge studies in man
}

\author{
D. A. J. TyrRelL \\ M.D., F.R.C.P., F.R.C.Path., F.R.S. \\ Clinical Research Centre, Watford Road, Harrow, Middlesex
}

\begin{abstract}
Summary
The only final test of the potency of a vaccine is its ability to protect against exposure in an epidemic. Laboratory tests for control purposes attempt to predict this capacity. It is suggested that challenging small groups of volunteers with attenuated influenza virus is a good index of immunity which could be used to check and refine present tests and to evaluate new ones.
\end{abstract}

\section{Introduction}

When standardizing and controlling influenza and other vaccines it is clearly essential to have exact information on the antigens it contains and the amount of each. Methods are available to deal with some of the difficulties which arise, such as the differing antigenicity of vaccines put up with different adjuvants.

However, there may be a need for further information which any number of laboratory tests cannot provide. One might need to know, for example, whether the antigen evokes immunity against the virus in circulation in the community and whether it will induce a primary or a secondary (booster) type of response; this clearly depends not only on the vaccine but also on the antigens to which the vaccinee has been exposed and the imprint they have left on his immune system, a complex matter which at the moment cannot be mimicked in animals used in control laboratories, although this may yet become possible (Potter et al., 1973). Further, the same antigens may be administered by a number of different routes, and the response by these may not be exactly predicted by laboratory tests because of difference in the physical state of the antigens and their mode of administration-a good example is the administration of killed vaccine by spray or in a fluorocarbon propellant. In this case circulating or local antibodies may be a poor guide to the resistance to infection induced in the respiratory tract. Then again, the effectiveness of a live vaccine obviously depends not only on its antigenic composition but on how and where it replicates in the respiratory tract. The ferret may be of some value here but can be only a rough guide to what happens in man. Finally, the really important index of the effectiveness of all vaccines is the degree to which they render the respiratory tract resistant to infection with the current serotype of virus. This is particularly obvious when one is comparing vaccines which are compounded in different ways or administered by different routesantibody responses may not be comparable either qualitatively or quantitatively and the question at issue is not which produces the best antibody of a certain sort or in a certain compartment but 'what is the net effect on the resistance of the host to infection?'.

In the past the only way to get such answers was to conduct field trials and for this one requires large numbers of volunteers and vaccine, a substantial field organization, and good fortune in that the results will not be obtained unless there is a substantial epidemic at a suitable interval after the vaccine is given. The net result is that only relatively simple questions can be asked in such trials, such as 'Does this vaccine protect?'; it is very difficult to obtain quantitative comparisons of effectiveness which will withstand critical statistical analysis.

It would appear that challenging vaccinated volunteers with live virus can overcome many of these problems. There are ethical difficulties in giving an unmodified virus-one cannot exclude the risk of serious disease or possible permanent sequelae, and if volunteers are not isolated there is the chance of infecting contacts or even starting a local epidemic; if they are isolated there is the problem of keeping enough individuals in isolation long enough to get a sufficient number of results. It is now possible to obtain reliably attenuated influenza viruses, which will soon, it is hoped, be licensed as live vaccines. These can be used for challenge as well as immunization. Admittedly the virus is modified, but $10^{7} \mathrm{EID}_{50}$ represents a relatively small number of human infectious doses and the administration by nasal drops or spray is, in a general way, similar to natural exposure, which is presumably by a droplet which lands on the nasal or lower respiratory epithelium. Clearly it can be used in non-isolated volunteers without worries about the occurrence of disease or epidemics.

\section{A representative trial}

It is not necessary to give a complete listing of the ways in which such a procedure has already given 
TABLE 1. Objectives of trials using challenge with live attenuated influenza virus

(1) Comparison of effectiveness of killed with live influenza B virus vaccines (Beare et al., 1968).

(2) Comparison of saline and oil-adjuvant influenza $A$ vaccine with live attenuated virus (Freestone et al., 1972).

(3) Test of effectiveness of intranasal killed influenza A vaccine (Potter et al., 1975).

(4) Relative effectiveness of standard killed vaccine and one prepared from a mutant with an earlier serotype.

TABLE 2. Results of challenge of student volunteers with attenuated influenza $A\left(\mathrm{H}_{3} \mathrm{~N}_{2}\right)$

\begin{tabular}{lcccc}
\hline & \multicolumn{2}{c}{$\begin{array}{c}\text { Result of challenge with } \\
\text { recombinant WRL 105 } \\
\text { (Finland 74 serotype) }\end{array}$} \\
\cline { 3 - 5 } \multicolumn{1}{c}{$\begin{array}{c}\text { Inactivated } \\
\text { vaccine } \\
\text { given }\end{array}$} & $\begin{array}{c}\text { GM HI titre } \\
\text { v. challenge } \\
\text { serotype }\end{array}$ & $\begin{array}{c}\text { Virus } \\
\text { isolation }\end{array}$ & $\begin{array}{c}\text { HI antibody } \\
\text { rise }\end{array}$ & $\begin{array}{c}\text { Virus isolated } \\
\text { or antibody } \\
\text { rise }\end{array}$ \\
\hline $\begin{array}{l}\text { Standard influenza A } \\
\text { (Port Chalmers 73) }\end{array}$ & 217 & $0 / 40$ & $2 / 36$ & $2 / 41$ \\
$\begin{array}{l}\text { Strain 30c } \\
\begin{array}{l}\text { Standard influenza B } \\
\text { (Hong Kong 73) }\end{array}\end{array}$ & 100 & $1 / 46$ & $9 / 47$ & $10 / 49$ \\
\hline
\end{tabular}

The volunteers were students at the University of Sheffield and staff at Wellcome Research Laboratories, Berkhamsted. They received the inactivated vaccine i.m. and several weeks later the live vaccine $10^{7} \mathrm{EID}_{50}$ as nasal drops. Virus isolation was attempted 2 days later. A full report is in preparation.

valuable information but four studies are listed in Table 1. The last is a collaborative study of the Medical Research Council influenza trials subcommittee, and a preliminary analysis of the results is given in Table 2. A full account is in preparation. The figures given show that there is clear evidence that the 30c strain gave some protection, and that this was substantially less than that conferred by standard vaccine. The degree of protection seen in these and other such studies with killed vaccine is comparable with that found in trials in epidemics. The protection was greater than expected, and it would have been advantageous to have arranged the trial so as to get some idea how long it persisted. This study also shows that, by using such a method of study, it would be possible to tackle the vexed question of how to define that degree of relationship (between the antigens of the vaccine and that of the epidemic strain) which is sufficient for good protection to be induced. The answer will surely come by comparing the results of the quantitative angtiv genic studies described in other papers with testsof of immunity in vaccinated volunteers.

\section{References}

Beare, A.S., Hobson, D., Reed, S.E. \& Tyrrell, D.A.而 (1968) A comparison of live and killed influenza virus vaccines. Lancet, ii, 418.

Freestone, D.S., Hamilton-Smith, S., Schild, G.C., Buck land, R., Chinn, S. \& Tyrrell, D.A.J. (1972) Antibod干 responses and resistance to challenge in volunteers vaccE nated with live attenuated, detergent split and oil adjuvant A2/Hong Kong/68 $\left(\mathrm{H}_{3} \mathrm{~N}_{2}\right)$ influenza vaccines. Journal $\$$ Hygiene, 70, 531.

Potter, C.W., Jennings, R., Mclaren, C. \& Clarke, (1975) Immunity following intranasal administration of a inactivated, freeze-dried A/England/42/72 vaccine. Archive of Virology, 48, 307.

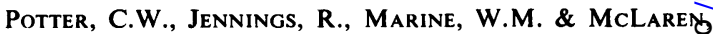
C. (1973) Potentiation of the antibody response io inact vated A2/Hong Kong vaccines by previous heterotypie influenza virus infectton. Microbios, 8, 101. 